\title{
Antioxidant and antimicrobial activities of ginger with aging and fermentation
}

\author{
Young-Ho Seo* \\ Department of Food and Nutrition, Wonkwang Health Science University, Iksan 54538, Korea
}

\section{발효숙성생강의 항산화 및 항균 활성}

\author{
서영호* \\ 원광보건대학교 식품영양과
}

\begin{abstract}
Zingiber officinale Roscoe, commonly known as ginger, has long been used as a powerful health-promoting antioxidant that supports cellular health of the human body. The objective of this study was to compare the antioxidant and antimicrobial activities of the samples with aging and fermentation. Antioxidant activities of the samples were compared using total phenol, flavonoid contents, ABTS cation radical scavenging activity and DPPH radical scavenging activity. Antimicrobial activities were also examined using the paper disc method and minimum inhibitory concentration (MIC). Acidity of the fermented ginger (FG) with lactic acid bacteria showed a significantly higher value than that of the ginger (GG). The content of 6-gingerol, a bioactive component in ginger, decreased in all fermented gingers but 6-shogaol which is also one of the main valuable ingredients showed the increased content at ginger fermented with Streptococcus thermophilus and Lactobacillus acidphilus. Flavonoid contents of the FG and GG did not show significant differences. However, ABTS cation radical scavenging activity and DPPH radical scavenging activity were $10-30 \%$ increased in the samples with fermentation $(p<0.05)$, respectively. The samples of the disc showed an inhibitory effect on growth of gram positive Staphylococcus aureus and Listeria monocytogenes. Zinger with fermentation showed higher antioxidant and antimicrobial activities. Thus, we conclude that aging and fermentation can be a helpful process to increase the functional effects of ginger.
\end{abstract}

Key words : ginger, aging, fermentation, antioxidant, antimicrobial

\section{서 론}

근래 들어 식물자체의 기능성을 이용한 건강기능성 식품 개발이 활발하게 진행되고 있다. 건강기능성 식품 중 식물 추출물 발효식품(plant extract fermented food)은 식용식물 을 압착 또는 당류의 삼투압으로 얻은 추출물을 자체 발효 또는 미생물 등으로 발효하여 만든 식품이다. 식물추출물 은 미생물을 이용하여 발효시키면 미생물에 의해 유기화합

*Corresponding author. E-mail : yhseo@wu.ac.kr Phone : 82-63-840-1534, Fax : 82-63-840-1530

Received 6 December 2017; Revised 16 December 2017; Accepted 18 December 2017.

Copyright (c) The Korean Society of Food Preservation. All rights reserved.
물이 화학적으로 분해되고, 식물체에 함유 되어 있는 효소 들이 활성화되어 영양소의 흡수율을 높일 수 있는 장점이 있다(1).

생강(Zingiber offcinale Roscoe)은 생강과에 속하는 다년 생 허브작물로 인도, 말레이시아 등 아열대, 또는 열대 원산 의 초본식물 중 하나이며, 그 근경은 특유의 맛과 향기를 지니고 있어 생생강(fresh ginger), 건생강(dried ginger), 올 레오레진, 정유 등의 형태로 유통되며 식용, 약용, 또는 화장 품용으로 널리 사용되고 있다(2). 생강은 오랫동안 향신료 로 사용되어 왔으며 건위, 발한 등의 약리작용을 가지고 있어 기능성 식품 소재로 이용범위가 확대되고 있다 $(3,4)$. 생강의 80-90\%는 수분이고, 전분이 전체 고형분의 $40-60 \%$ 를 차지하고 있으며(5,6), 생강의 주요성분으로는 탄화수소 류, 케톤류, 알콜류를 비롯하여 zingiberene, $\gamma$-cardinen 등의 
휘발성 향기성분, 그리고 zingiberol, zingiberene 등의 정유 성분이 보고되고 있는데 특히 정유성분 중 생강의 매운맛을 내게 하는 주 성분인 6-gingerol 및 6-shogaol은 항산화, 항염 증의 특성을 가지고 있어 건강식품소재로서 많은 주목을 받고 있다 (7,8). 생강에 함유된 6-gingerol은 아스코르브산 의 $95 \%$ 정도에 해당하는 항산화 활성을 갖으며(9), 또한 $\beta$-카로틴을 안정화시킨다고 하였다(10). Hong(11)은 생강 으로부터 에테르로 추출한 gingerol이 BHA, 토코페롤보다 강한 항산화효과를 나타내었다고 하였으며 Fujio 등(12)도 생강으로부터 분리한 shogaol과 zingerone도 유지의 산화를 억제하는 효과가 있다고 보고한 바 있다. 이 외에도 항산화 효과(13), 트롬복산 생성(14), 대식세포의 활성화(15), NK 세포의 활성화(16), COX-1 효소 활성의 저해(17) 등과 같이 생강에 대한 많은 연구가 진행되어 생강의 다양한 생리활성 이 입증되고 있다. 생강은 주로 식품의 부재료로 사용되고 있지만, $10^{\circ} \mathrm{C}$ 이하에서 저온장해를 일으키고 $18^{\circ} \mathrm{C}$ 이상에서 발아하며, 최적 저장조건인 $10-15^{\circ} \mathrm{C}$, 상대습도 $80-90 \%$ 에서 도 장기간 생강을 저장-유통하는 것은 매우 어려운 실정이 다 $(18,19)$. 그러므로 생강의 유통기한 연장과 더불어 고부 가 가치를 창출할 기능성 생강제품 개발이 필요한 실정이 다. 이와 관련한 연구로는 유산균 균주를 사용하여 발효시 킨 생강의 품질특성(20)과 흑생강 제조 후 이를 이용한 음료 제조에 관한 보고(19) 등이 있다. 최근 발효기술을 통해 마늘을 가공하는 흑마늘 제조법(21)을 응용하여 흑생강을 제품화하고 있지만, 아직 생강의 발효와 숙성에 대한 연구 는 미흡한 상태이며, 특히 발효와 숙성을 동시에 처리한 발효숙성생강에 대한 연구는 거의 이루어지지 않은 실정이다. 따라서 본 연구는 생강의 숙성 후 유산균 발효과정을 통하여 발효숙성생강을 제조하고, 이의 항산화활성과 항균 성을 평가함으로서 생강의 가공 적성을 높이고 새로운 생강 을 이용한 건강 식품 소재로서의 적합성을 검토하고자 하였 다.

\section{재료 및 방법}

\section{재 료}

본 실험에서 사용한 생강은 전북 완주군 봉동면 생강산 지에서 구매한 국내산 생강(Zingiber offcinale Roscoe)을 수 세한 후 껍질을 제거하여 사용하였다. 6-gingerol, 6-shogaol 표준품은 Wako사(Waco pure chemicals, Osaka, Japan)에서 구입한 특급시약을 사용하였으며, HPLC 분석 용매는

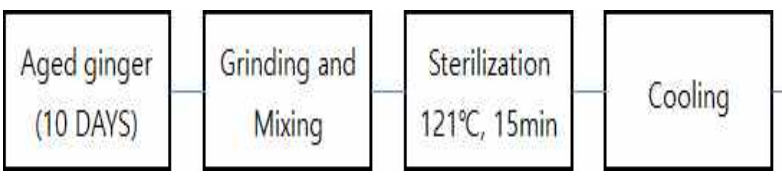

Fig. 1. Manufacturing process of aged and fermented ginger.
J. T. Baker사(Phillipsburg, NJ, USA) 제품을 구입하여 사용 하였다.

\section{생강 숙성}

생강의 숙성은 자체성분의 화학적 변환으로 생리활 성물질의 증가를 가져올 수 있다. 생강의 숙성은 항온항습 기(Temi 850, Asung Tech, Gimhae, Korea)를 사용하였으며, 원료생강을 수세하여 stainless통에 고르게 넣고 $80^{\circ} \mathrm{C}, 85 \%$ 조건의 항온항습기에서 10 일간 숙성시킨 후 사용하였다.

\section{발효숙성생강 추출액 제조}

발효숙성생강 추출액 제조는 Fig. 1과 같다. Starter 균주 로는 낙농제품 및 김치 유래 유산균인 Leuconostoc mesenteroides (KCTC 3505), Lactobacillus brevis(KCTC 3985), Streptococcus thermophilis(KCTC 3779), Lactobacillus acidphilus(KCTC 3140)를 사용하였으며, 한국미생물보존센터에서 분양받아 명시된 조건에 따라 72시간 계대배양하여 활성화시켰다. 활성화 된 균주는 MRS 배지(Difco company, Detroit, MI, $\mathrm{USA}$ )에서 배양하여 초기 균수가 $4-5 \times 10^{5} \mathrm{CFU} / \mathrm{mL}$ 에 도달 하면, 10 일간 숙성된 생강 $100 \mathrm{~g}$ 을 $500 \mathrm{~mL}$ 증류수와 혼합하 여 마쇄 및 접종한 후, 배양 $\left(37^{\circ} \mathrm{C}, 24\right.$ 시간)하여 발효숙성생 강을 제조하였다. 배양시간은 예비실험을 거쳐 결정하였으 며, 발효숙성생강 추출액은 발효숙성생강을 동결건조기 (Ilshin Biobase, Dongducheon, Korea)를 사용하여 급속동결 한 후 $5 \mathrm{mTorr}$ 의 감압조건하에서 건조하였다. 동결건조된 발효생강 $5 \mathrm{~g}$ 에 $80 \%$ 에탄올(Sigma Chemical Co., St. Louis, $\mathrm{MO}, \mathrm{USA}) 50 \mathrm{~mL}$ 로 정용하여 24 시간 동안 추출하고 여과한 후, $80^{\circ} \mathrm{C}$ 에서 환류 냉각하여 ethanol을 제거한 후 시료로 사용하였다. 대조구로서 생강을 숙성 및 발효 처리 없이 동결건조 및 추출하여 제조하였다.

\section{일반성분}

시료의 일반성분 분석은 $\mathrm{AOAC(22)의} \mathrm{방법을} \mathrm{참고하여}$ 실시하였다. 수분함량은 $105^{\circ} \mathrm{C}$ 의 상압가열 건조법(J-DSA2, Jisico Co., Seoul, Korea), 회분은 $550^{\circ} \mathrm{C}$ 의 직접 회화법 (J-FM, Jeil science Co., Seoul, Korea)을 이용하여 분석하였 다. 지방의 함량은 산 분해법(OF-22GW, Jelotech, Seoul, Korea)으로 측정하였고 단백질의 함량은 micro- Kjeldahl의 질소 정량법(Foss tecator digestor auto \& Kjeltec auto 2300, Foss, MA, USA)을 사용하였으며, 탄수화물 함량은 100 에 서 수분, 조회분, 조단백질, 조지방의 중량을 뺀 값으로 계산 하였다.

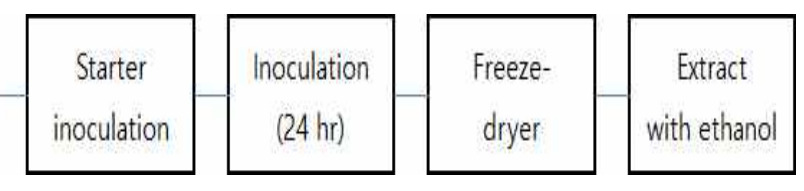


$\mathrm{pH}$ 및 산도측정

발효숙성생강의 $\mathrm{pH}$ 는 시료 $5 \mathrm{~g}$ 과 증류수 $45 \mathrm{~mL}$ 를 비이커 에 넣고 교반시킨 후 상등액을 $\mathrm{pH}$ meter(CP-411, Sechang Instruments., Ltd., Seoul, Korea)로 측정하였다. 시료의 산도 측정은 각 시료 $5 \mathrm{~g}$ 과 증류수 $5 \mathrm{~g}$ 을 혼합하여 $0.1 \mathrm{~N}$ $\mathrm{NaOH}$ (Sigma Chemical Co., St. Louis, MO, USA)로 pH가 8.3 이 될 때까지 적정하여 시료 $5 \mathrm{~g}$ 을 중화하는데 필요한 $\mathrm{NaOH}$ 의 양을 젖산으로 환산하여 산도(\%,w/v)로 나타내었 다.

\section{6-gingerol 및 6-shogaol 분석}

생강의 지표성분이라 할 수 있는 6-gingerol과 6-shogaol 의 함량의 분석은 발효숙성생강 $2 \mathrm{~g}$ 을 $\mathrm{MeOH} 5 \mathrm{~mL}$ 에 넣어 초음파 추출(1시간)을 한 후에 원심분리 $(3,000 \mathrm{rpm}, 20$ 분) 하고 여과한 상등액 $10 \mu \mathrm{L}$ 를 $\mathrm{HPLC}$ 에 주입하여 Table 1 와 같은 조건에서 각각의 표준곡선을 작성하여 정량분석 하였 다.

Table 1. Operating conditions of HPLC in analysis of 6-gingerol and 6-shogaol

\begin{tabular}{cc}
\hline Items & Condition \\
\hline Instrument & Agilent UV 1200 system \\
Column & $\mathrm{RP} 18$ \\
Column oven & $25^{\circ} \mathrm{C}$ \\
Detector & $\mathrm{UV} \mathrm{detector}$ \\
Absorbance & $282 \mathrm{~nm}$ \\
Flow rate & $1.0 \mathrm{~mL} / \mathrm{min}$ \\
Mobile phase & Isocratic(MeOH:D.W=80:20) \\
Injection volumn & $10 \mu \mathrm{L}$ \\
\hline
\end{tabular}

\section{총 페놀함량}

총 페놀함량은 시료의 페놀성화합물과 시약이 반응하여 청색으로 발색되는 Folin-Denis method를 응용하여(23) 분 석하였다. 각각의 시료 추출물을 10 배 희석하여 사용하였 으며, 희석액 $1 \mathrm{~mL}$ 와 50\% Folin-Ciocalteu reagent(Sigma Chemical Co.) $2 \mathrm{~mL}$ 를 혼합하여 실온에서 3 분간 방치한 후, $10 \% \mathrm{Na}_{2} \mathrm{CO}_{3}$ (Sigma Chemical Co.) $1 \mathrm{~mL}$ 를 혼합하고 vortex하여 실온에서 30 분간 반응시켜 분광광도계(SP2000UV, Woongi Science Co., Seoul, Korea)를 이용하여 $760 \mathrm{~nm}$ 에서 흡광도를 측정하였다. 표준곡선은 gallic acid를 표준물질로 하여 $\mathrm{mg} \mathrm{GAE} / \mathrm{g}$ 으로 작성하였으며 3회 반복 실험하여 측정하였다.

\section{총 플라보노이드함량}

발효숙성생강 추출액의 총 플라보노이드 함량은 Moreno $\mathrm{MI}$ 등(24)의 방법을 적용하여 측정하였다. 10 배 희석한 각 시료 추출물 $1 \mathrm{~mL}$ 에 $5 \% \mathrm{NaNO}_{2}$ (Sigma Chemical Co.) 300 $\mu \mathrm{L}$ 를 가하여 5 분간 방치한 후, $10 \% \mathrm{AlCl}_{3} \cdot 6 \mathrm{H}_{2} \mathrm{O}(\mathrm{Sigma}$ Chemical Co.) $600 \mu \mathrm{L}$ 를 가하여 다시 5 분간 방치하였으며, $1 \mathrm{~N} \mathrm{NaOH}$ (Sigma Chemical Co.) $2 \mathrm{~mL}$ 를 가하여 vortex 한 후 실온의 암소에서 30 분간 반응시켰다. $510 \mathrm{~nm}$ 에서 분광 광도계(SP-2000UV, Woongi Sciences Co.)를 사용하여 흡광 도를 측정하였고, 표준물질로 naringin(Sigma Chemical Co.) 을 분석하여 작성한 검량선에 흡광도를 대입하여 총 플라보 노이드 함량 $(\mathrm{mg} \mathrm{NE} / 100 \mathrm{~g})$ 을 산출하였다.

\section{ABTS radical 소거활성}

ABTS radical 소거활성은 $\operatorname{Re}$ 등(25)의 방법을 적용하여 측정하였다. 2,2'-azino-bis(3-ethylbenzothiazoline-6sulphonic acid)(Sigma Chemical Co.)와 potassium persulfate(Sigma Chemical Co.)를 혼합하면 양이온이 생성 되고 시료와 반응하여 생성된 양이온이 소거됨으로써 청록 색이 탈색되며 이 흡광도를 측정하여 항산화 활성을 측정할 수 있다. $7.4 \mathrm{mM} \mathrm{ABTS}$ 용액에 $2.6 \mathrm{mM}$ potassium persulfate 를 혼합하여 실온의 암소에서 약 24 시간 동안 양이온을 형성시킨 후, $732 \mathrm{~nm}$ 에서 흡광도 값이 $1 \pm 0.1$ 이 되도록 phosphate buffer saline(pH 7.4)으로 희석하여 사용하였다. ABTS solution $1,995 \mu \mathrm{L}$ 와 10 배 희석된 각 시료추출물 1 $\mathrm{mL}$ 를 vortex하고 암소에서 30 분간 반응시켜 $735 \mathrm{~nm}$ 에서 흡광도를 측정(SP-2000UV, Woongi Sciences Co.)하였다. 결과값은 시료 첨가군과 무첨가군을 비교하여 radical 소거 활성을 백분율(\%)로 나타내었다. 이 때 무첨가군은 시료와 동량의 $99.9 \%$ 에탄올을 사용하여 대조군으로 하였다.

\section{$\mathrm{DPPH}$ 전자공여능 측정}

발효숙성생강 추출액의 1.1-diphenyl-2-picrylhydrazyl $(\mathrm{DPPH})$ 전자공여능 측정은 10 배 희석된 시료 추출물 0.6mL에 $0.4 \mathrm{mM} \mathrm{DPPH(Sigma} \mathrm{Chemical} \mathrm{Co.)용액} 2.4 \mathrm{~mL}$ 를 가하여 교반한 후 실온에서 30 분간 반응시켰다. 분광광도 계(SP-2000UV, Woongi Sciences Co.)를 이용하여 $517 \mathrm{~nm}$ 에서 3회 반복하여 흡광도를 측정하였고, 시료 무첨가군과 비교하여 DPPH 전자공여능을 산출하였다. 이 때 무첨가군 은 시료와 동량의 $99.9 \%$ 에탄올을 사용하여 대조군으로 하였다.

\section{항균 활성}

항균 활성 검사를 위해 디스크 확산법(paper discmethod) 을 통해 측정하였다(26). 그람양성균주로서 Staphylococcus aureus(KCCM 11335), Listeria monocytogenes(KCCM 40307)을 사용하였고, 그람음성균주는 Salmonella spp. (ATCC 14028), Escherichia coli(KCCM 11591)를 사용하였 다. 배지는 tryptic soy broth(Difco Laboratories, Detroit, MI, USA)와 tryptic soy agar(Difco), nutrient broth 및 $\operatorname{agar(Difco)}$ 를 생육 배지로 사용하였다. Tryptic soy broth Agar와 
nutrient agar $15 \mathrm{~mL}$ 에 균 배양액 $0.5 \mathrm{~mL}$ 를 주입한 후, 그 위에 각각의 배지 $5 \mathrm{~mL}$ 를 중층하여 생육배지로 사용하였 다. 발효생강 추출물은 $100 \mu \mathrm{g} / \mathrm{mL}$ 농도로 $60 \mu \mathrm{L}$ 를 paper disc에 완전히 흡수시켜 최종 농도를 $6 \mathrm{mg} / \mathrm{disc}$ 로 하고, 배지 표면에 밀착시킨 후 각 균주의 배양 온도조건에 따라 24시 간 배양하였다. 항균력은 disc 주위의 clear zone의 직경 $(\mathrm{cm})$ 을 3 회 반복 측정하여 비교하였다.

최소억제농도(MIC, minimal inhibitory concentration)

균주에 대한 최소억제농도(minimum inhibitory concentration, $\mathrm{MIC}$ )는 broth micro dilution method에 의해 분석하였다(26). 시험관에 Tryptic soy broth(Difco)를 $0.5 \mathrm{~mL}$ 씩 분주하여 시험균 배양액 $1 \mathrm{~mL}$ 를 제 1 시험관에 넣고 혼합한 후, 0.5 $\mathrm{mL}$ 를 취해 제 7 시험관까지 넣어 교반시켜 $4.00,3.00,2.00$, $1.00,0.50,0.25,0.13 \mathrm{mg} / \mathrm{mL}$ 의 농도로 희석하였다. $37^{\circ} \mathrm{C}$ 에 서 24시간 배양한후, $560 \mathrm{~nm}$ 에서 흡광도를 측정 (SP-2000UV, Woongi Sciences Co.)하여 탁도가 나타나지 않은 시험관의 농도를 $\mathrm{MIC}$ 값으로 측정하였다.

\section{통계분석}

통계분석은 SPSS Statistics(ver. 20.0, IBM Inc., New York, NY, USA)를 이용하여 평균표푼년차로 표시하였다. 일반생강과 발효숙성생강의 비교를 위해 Duncan's multiple range test에 의해 $\mathrm{p}<0.05$ 수준에서 유의성을 검정하였다.

\section{결과 및 고찰}

일반성분

생강과 발효숙성생강 추출물의 일반성분을 각 5 회씩 실 시한 결과는 Table 2 와 같다. 일반생강과 발효숙성생강 각 각 수분함량이 $9.5,7.6 \%$ 로 나타났으며, 조단백질은 8.5 , $11.6 \%$, 조지방은 $8.1,11.5 \%$, 회분은 $5.3,5.4 \%$ 로 나타났다.

Table 2. Proximate composition of ginger and fermented ginger medium

\begin{tabular}{ccccc}
\hline Sample & Moisture & Crude ash & Crude fat & Crude protein \\
\hline Ginger medium & $9.5 \pm 0.12^{\mathrm{a} 1)}$ & $5.3 \pm 0.09^{\mathrm{a}}$ & $8.1 \pm 0.14^{\mathrm{b}}$ & $8.5 \pm 0.05^{\mathrm{b}}$ \\
Fermented ginger medium & $7.6 \pm 0.22^{\mathrm{b}}$ & $5.4 \pm 0.15^{\mathrm{a}}$ & $11.5 \pm 0.12^{\mathrm{a}}$ & $11.6 \pm 0.06^{\mathrm{a}}$ \\
\hline
\end{tabular}

${ }^{11}$ Means $\pm \mathrm{SD}(\mathrm{n}=3)$ in a column followed by same letter are not significantly different by Duncan's multiple range test $(\mathrm{p}<0.05)$.

\section{$\mathrm{pH}$ 및 산도}

생강과 발효숙성생강 추출물의 $\mathrm{pH}$ 와 산도를 분석한 결 과는 Table 3 과 같다. 생강 추출물의 $\mathrm{pH}$ 는 6.68 산도는 0.39 로 나타났으며, 생강을 발효숙성 시켰을 때 $\mathrm{pH}$ 는 감소하였 으며, 산도는 전반적으로 증가한 것을 확인할 수 있었다.
특히 Streptococcus thermophilis로 발효시킨 생강의 산도가 유의적으로 가장 높음을 확인할 수 있었다. Aspergillus oryzae로 발효한 자색당근을 첨가한 발효유의 품질 및 관능 특성에 관한 연구(27)에서도 시료의 발효가 진행됨에 따라 $\mathrm{pH}$ 가 감소하는 경향을 보였으며, 산도는 증가하는 결과를 보여 본 연구와 유사한 경향을 나타내었다. 이는 미생물이 생강의 유기물을 분해하고 대사산물을 축적하는 발효과정 을 통해 유기산의 축적이 이루어지면서 $\mathrm{pH}$ 는 낮아지고, 산도는 증가하는 결과를 보인 것이다.

Table 3. $\mathrm{pH}$ and acidity of the fermented ginger

\begin{tabular}{lcc}
\hline \multicolumn{1}{c}{ Samples } & $\mathrm{pH}$ & Acidity \\
\hline Ginger medium & $6.68 \pm 0.02^{\mathrm{a}}$ & $0.39 \pm 0.07^{\mathrm{b}}$ \\
Ginger fermented with Leuconostoc mesenteroides & $6.35 \pm 0.05^{\mathrm{ab}}$ & $0.47 \pm 0.01^{\mathrm{ab}}$ \\
Ginger fermented with Lactobacillus brevis & $6.30 \pm 0.03^{\mathrm{b}}$ & $0.52 \pm 0.02^{\mathrm{ab}}$ \\
Ginger fermented with Streptococcus thermophills & $6.28 \pm 0.02^{\mathrm{b}}$ & $0.55 \pm 0.01^{\mathrm{a}}$ \\
Ginger fermented with Lactobacillus acidphilus & $6.31 \pm 0.02^{\mathrm{b}}$ & $0.49 \pm 0.03^{\mathrm{ab}}$ \\
\hline
\end{tabular}

${ }^{1)}$ Means \pm SD ( $\mathrm{n}=3$ ) in a column followed by same letter are not significantly different by Duncan's multiple range test $(\mathrm{p}<0.05)$.

\section{6-gingerol 및 6-shogaol}

생강의 숙성과 발효 과정 중 유용성분인 6-gingerol과 6-shogaol의 성분변화를 알아보기 위해 HPLC를 이용하여 6-gingerol과 6-shogaol의 양을 측정한 결과는 Table 4와 같 다. 발효를 시키지 않은 생강의 6-gingerol 함량은 404.8 $\mathrm{\mu g} / \mathrm{g}$ 이었으며, 6-shogaol은 검출되지 않았다. 그리고 숙성 과 발효를 시킨 발효숙성생강 추출물의 6-gingerol 함량은 71.1-92.5 $\mu \mathrm{g} / \mathrm{g}$ 로 줄어들었지만, 6-shogaol 함량은 128.8$196.4 \mu \mathrm{g} / \mathrm{g}$ 로 증가하여 발효숙성 과정 중 6-gingerol이 6-shogaol로 변환되었음을 확인할 수 있었다. 6-gingerol은 생강에 함유되어 있는 매운맛 성분으로 알려져 있으며, 6-shogaol은 신선한 원료 생강에는 거의 존재하지 않고, 생 강의 열처리 가공 중에 증가하는 것으로 알려져 있다(28). 그러므로 생강의 발효숙성과정을 통해 매운맛이 상당량 감소된 것으로 판단된다. 또한 Chun과 Chung(20)이 생강을

Table 4. Contents of 6-gingerol and 6-shogaol

\begin{tabular}{lcc}
\hline \multirow{2}{*}{ Samples } & \multicolumn{2}{c}{ Contents $(\mu \mathrm{g} / \mathrm{g})$} \\
\cline { 2 - 3 } & 6-gingerol & 6-shogaol \\
\hline Ginger medium & $404.8 \pm 2.9$ & $\mathrm{ND}^{2)}$ \\
Ginger fermented with Leuconostoc mesenteroides & $86.2 \pm 1.6^{\mathrm{al}}$ & $149.4 \pm 1.5^{\mathrm{b}}$ \\
Ginger fermented with Lactobacillus brevis & $92.5 \pm 2.2^{\mathrm{a}}$ & $128.8 \pm 0.7^{\mathrm{b}}$ \\
Ginger fermented with Streptococcus thermophilis & $75.6 \pm 1.5^{\mathrm{b}}$ & $173.8 \pm 0.9^{\mathrm{a}}$ \\
Ginger fermented with Lactobacillus acidphilus & $71.1 \pm 1.9^{\mathrm{b}}$ & $196.4 \pm 1.1^{\mathrm{a}}$ \\
\hline
\end{tabular}

${ }^{1}$ Means \pm SD ( $\left.n=3\right)$ in a column followed by same letter are not significantly different by Duncan's multiple range test $(\mathrm{p}<0.05)$.

${ }^{2} \mathrm{ND}$, not detected 
유산균으로 발효했을 때 6-shogaol이 생강의 제조, 가공, 저장 중에 탈수와 레트로-알돌반응에 의하여 생긴다는 것 과도 일치한다. L. plantarum, L. mesenteroides로 발효된 생 강의 6-shogaol 함량은 각각 $173.8,196.4 \mu \mathrm{g} / \mathrm{g}$ 검출되었으며, S. thermophilus, L. acidphilus로 발효된 생강은 각각 173.8, $196.4 \mathrm{\mu g} / \mathrm{g}$ 검출되었다.

\section{총 페놀 및 총 플라보노이드}

발효숙성생강 추출물의 총 페놀과 총 플라보노이드 함량 분석 결과는 Table 5 와 같다. 생강추출물과 비교하여 발효 숙성생강 추출물의 총페놀 함량은 낮게 나타났으나, 총 플 라보노이드 함량은 유의적인 차이가 없는 것을 확인할 수 있었다. 특히 발효숙성된 생강 중에서는 $S$. thermophilus, L. acidphilus로 발효된 생강의 총 페놀 함량이 유의적으로 높았다. 그리고 플라보노이드 함량은 $S$. thermophilus로 발 효된 생강이 가장 높게 나타났으나, 유의적인 차이는 없었 다. 식물에 다량 존재하는 플라보노이드 화합물은 낮은 redox potential로 전자를 다른 화합물에 쉽게 공여하므로 활성산소종을 효과적으로 소거할 수 있기 때문에 체내에서 항암, 항산화, 항균작용, 순환기 질환 예방, 항염증, 항 바이 러스, 면역증강 등의 생리활성적 기능성을 도와준다고 보 고된 바 있다(29).

\section{ABTS radical 소거활성 및 DPPH 전자공여능}

ABTS radical 소거 활성측정법은 혈장에서 양이온 라디 컬의 흡광도가 항산화제에 의해 억제되는 것에 기초하여 개발된 방법으로 $\mathrm{ABTS}$ 와 potassium persulfate를 암소에 방
치하였을 때 시료의 항산화력에 의해 ABTS radical이 소거 되어 라디컬 특유의 청록색이 탈색되는 정도를 흡광도 값으 로 나타내어 측정하는 방법이다. ABTS radical 소거 활성은 Table 6에서 나타난 바와 같이 발효숙성된 생강추출물이 $88.11-101.32 \%$ 로 일반 생강의 $65.43 \%$ 와 비교하여 상대적 으로 높은 항산화 결과를 보였다. DPPH 전자공여능은 방향 족 화합물과 아민류에 의해 환원되어 자색이 탈색되는 정도 를 측정하는 것으로 다양한 추출물로부터 항산화활성을 측정하는데 효과적으로 사용된다. DPPH 전자공여능 측정 에서도 발효숙성 생강추출물의 값이 $80.55-89.41 \%$ 로 일반 생강추출물 $68.68 \%$ 에 비해 높게 나타났다. 특히 $S$. thermophilus와 L. acidphilus의 함량이 89.41, 87.89\%로 높 은 수치를 나타내었다.

\section{항균활성}

일반생강 추출액과 발효숙성생강 추출액의 항균효과를 디스크 확산법으로 비교한 결과는 Table 7과 같다. S. aureus 균주의 plate에서 생강추출액의 clear zone 직경이 $2.36 \mathrm{~cm}$ 로 나타났으며 발효숙성생강 추출액은 2.88-3.65 cm로 측정되 어 발효숙성생강추출액의 항균활성이 유의적으로 더 높은 것을 확인하였으며, 특히 L brevis로 발효시킨 생강 추출물 의 항균활성이 가장 높은 것으로 나타났다. $L$. monocytogenes 균주에서도 발효숙성생강 추출물의 항균활 성이 우수한 것으로 나타나, 생강의 발효숙성 공정을 통해 그람양성균인 S. aureus와 L monocytogenes 균에 대해 항균 활성이 있음을 확인하였다. 또한 일반생강 추출액은 그람 음성균이 Salmonella spp. 와 E. coli 균주에는 clear zone이 형성되지 않아 생육저해 활성이 미비한 것으로 나타났다.

Table 5. Total phenol and flavonoid contents of the fermented ginger

\begin{tabular}{lcc}
\hline \multicolumn{1}{c}{ Samples } & $\begin{array}{c}\text { Total phenol contents } \\
(\mathrm{mg} \mathrm{GAE} / \mathrm{g})\end{array}$ & $\begin{array}{c}\text { Total flavonoid contents } \\
(\mathrm{mg} \mathrm{NE} / 100 \mathrm{~g})\end{array}$ \\
\hline Ginger medium & $38.92 \pm 0.25^{\mathrm{a})}$ & $634.42 \pm 2.2^{\mathrm{a}}$ \\
Ginger fermented with Leuconostoc mesenteroides & $29.14 \pm 0.24^{\mathrm{b}}$ & $630.38 \pm 1.5^{\mathrm{a}}$ \\
Ginger fermented with Lactobacillus brevis & $30.63 \pm 0.44^{\mathrm{b}}$ & $628.43 \pm 2.3^{\mathrm{a}}$ \\
Ginger fermented with Streptococcus thermophilus & $34.15 \pm 0.21^{\mathrm{ab}}$ & $631.88 \pm 3.7^{\mathrm{a}}$ \\
Ginger fermented with Lactobacillus acidphilus & $33.67 \pm 0.52^{\mathrm{ab}}$ & $630.12 \pm 1.1^{\mathrm{a}}$ \\
\hline
\end{tabular}

${ }^{1)}$ Means $\pm \mathrm{SD}$ ( $\mathrm{n}=3$ ) in a column followed by same letter are not significantly different by Duncan's multiple range test $(\mathrm{p}<0.05)$.

Table 6. ABTS and DPPH radical scavenging activites of the fermented ginger

\begin{tabular}{lcc}
\hline \multicolumn{1}{c}{ Samples } & Scavenging activity of ABTS radical (\%) & Scavenging activity of DPPH radical (\%) \\
\hline Ginger medium & $65.43 \pm 1.23^{\mathrm{b}} \mathrm{b}^{\mathrm{l}}$ & $68.68 \pm 2.12^{\mathrm{b}}$ \\
Ginger fermented with Leuconostoc mesenteroides & $88.11 \pm 2.86^{\mathrm{a}}$ & $80.55 \pm 0.86^{\mathrm{a}}$ \\
Ginger fermented with Lactobacillus brevis & $90.82 \pm 1.22^{\mathrm{a}}$ & $80.98 \pm 2.58^{\mathrm{a}}$ \\
Ginger fermented with Streptococcus thermophilus & $101.32 \pm 1.45^{\mathrm{a}}$ & $89.41 \pm 2.09^{\mathrm{a}}$ \\
Ginger fermented with Lactobacillus acidphilus & $96.44 \pm 0.67^{\mathrm{a}}$ & $87.89 \pm 2.76^{\mathrm{a}}$ \\
\hline
\end{tabular}

${ }^{1)}$ Means \pm SD ( $=3$ ) in a column followed by same letter are not significantly different by Duncan's multiple range test $(\mathrm{p}<0.05)$. 
Table 7. Antimicrobial activities of the fermented ginger

\begin{tabular}{lcccc}
\hline \multirow{2}{*}{ Samples } & \multicolumn{3}{c}{ Clear zone on plate (cm) } \\
\cline { 2 - 5 } & Staphylococcus aureus & Salmonella spp. & Listeria monocytogenes & Escherichia coli \\
\hline Ginger medium & $\left.2.36 \pm 0.17^{\mathrm{cl}}\right)$ & $\mathrm{ND}^{2}$ & $1.89 \pm 0.07^{\mathrm{b}}$ & $\mathrm{ND}$ \\
Ginger fermented with Leuconostoc mesenteroides & $2.88 \pm 0.23^{\mathrm{b}}$ & $2.38 \pm 0.13^{\mathrm{a}}$ & $2.41 \pm 0.05^{\mathrm{a}}$ & $\mathrm{ND}$ \\
Ginger fermented with Lactobacillus brevis & $3.65 \pm 0.11^{\mathrm{a}}$ & $1.88 \pm 0.14^{\mathrm{b}}$ & $2.85 \pm 0.24^{\mathrm{a}}$ & $\mathrm{ND}$ \\
Ginger fermented with Streptococcus thermophilus & $3.24 \pm 0.21^{\mathrm{b}}$ & $2.22 \pm 0.09^{\mathrm{a}}$ & $2.49 \pm 0.27^{\mathrm{a}}$ & $\mathrm{ND}$ \\
Ginger fermented with Lactobacillus acidphilus & $2.98 \pm 0.41^{\mathrm{b}}$ & $2.51 \pm 0.35^{\mathrm{a}}$ & $2.68 \pm 0.06^{\mathrm{a}}$ & $\mathrm{ND}$ \\
\hline
\end{tabular}

${ }^{1)}$ Means \pm SD $(n=3)$ in a column followed by same letter are not significantly different by Duncan's multiple range test $(\mathrm{p}<0.05)$.

${ }^{2)} \mathrm{ND}$, not detected.

\section{최소억제농도}

항균활성결과에 따라 발효숙성생강추출물의 정량적 항 균농도를 판단하기 위한 최소억제농도(MIC) 분석결과는 Table 8에 제시되었다. 디스크 확산법에 의해 clear zone을 형성하여 억제 균주로 확인되었던 $S$. aureus는 생강추출물 의 농도가 $2.00 \mathrm{mg} / \mathrm{mL}$ 에서는

Table 8. Minimal inhibitory concentration of the fermented ginger

\begin{tabular}{|c|c|c|c|c|c|}
\hline & \multirow{2}{*}{ Samples ${ }^{1)}$} & \multicolumn{4}{|c|}{ Concentration (mg/mL) } \\
\hline & & 4.00 & 2.00 & 1.00 & 0.50 \\
\hline \multirow{5}{*}{ Staphylococcus aureus } & GM & $\mathrm{I}^{2)}$ & I & $\mathrm{G}^{3)}$ & $\mathrm{G}$ \\
\hline & GFLM & I & I & I & I \\
\hline & GFLP & I & I & I & I \\
\hline & GFST & I & I & I & I \\
\hline & GFLA & I & I & I & I \\
\hline \multirow{5}{*}{ Salmonella spp. } & GM & I & G & G & $\mathrm{G}$ \\
\hline & GFLM & I & G & G & $\mathrm{G}$ \\
\hline & GFLP & I & G & G & G \\
\hline & GFST & I & I & G & G \\
\hline & GFLA & I & I & G & G \\
\hline \multirow{5}{*}{ Listeria monocytogenes } & GM & I & G & G & $\mathrm{G}$ \\
\hline & GFLM & I & I & G & $\mathrm{G}$ \\
\hline & GFLP & I & I & G & G \\
\hline & GFST & I & I & G & $\mathrm{G}$ \\
\hline & GFLA & I & I & G & $\mathrm{G}$ \\
\hline \multirow{5}{*}{ Escherichia coli } & GM & G & G & G & G \\
\hline & GFLM & G & G & G & $\mathrm{G}$ \\
\hline & GFLP & G & G & G & $\mathrm{G}$ \\
\hline & GFST & G & G & G & $\mathrm{G}$ \\
\hline & GFLA & $\mathrm{G}$ & $\mathrm{G}$ & $\mathrm{G}$ & $\mathrm{G}$ \\
\hline
\end{tabular}

${ }^{1)} \mathrm{GM}$, ginger medium; GFLM, ginger fermented with Leuconostoc mesenteroides, GFLP, ginger fermented with Lactobacillus plantarum, GFST, ginger fermented with Streptococcus thermophilis, GFLA, ginger fermented with Lactobacillus acidphilus. ${ }^{2)}$ I, inhbition

${ }^{3)} \mathrm{G}$, growth.
미생물이 억제되었고, $1.00 \mathrm{mg} / \mathrm{mL}$ 에서는 미생물 생장이 관찰되어 $1.00-2.00 \mathrm{mg} / \mathrm{mL}$ 의 MIC 값을 보였다. 전반적으로 발효숙성생강추출물이 생강추출물보다 더 낮은 MIC 값을 나타내어 항균활성이 더 큰 것으로 측정되었다. 하지만 $E$. coli에서는 생강 추출물 및 발효숙성생강 추출물 모두 억제 효과가 없는 것으로 나타났다.

\section{요 약}

본 연구는 생강의 천연 기능성 식품소재로서 활용성을 높이기 위해 마쇄한 생강과 숙성 후 발효시킨 생강을 이용 하여 항산화 및 항균활성의 특성을 비교하였다. 생강 추출 물의 $\mathrm{pH}$ 는 6.68 산도는 0.39로 나타났으며, 생강을 발효숙 성 시켰을 때 $\mathrm{pH}$ 는 감소하였으나, 산도는 전반적으로 증가 하였다. 일반 생강의 6-gingerol 함량은 $404.8 \mathrm{\mu g} / \mathrm{g}$ 이었으며, 6-shogaol은 검출되지 않았으나, 발효숙성생강 추출물의 6-shogaol 함량은 128.8-196.4 $\mathrm{\mu g} / \mathrm{g}$ 로 증가하여 발효숙성 과정 중 6-gingerol이 6-shogaol로 변환되었음을 확인할 수 있었다.

총 페놀함량과 총 플라보노이드 함량 분석결과, 일반생 강 추출물의 총페놀 함량이 높았으며, 총 플라보노이드 함 량의 유의차는 없었다. ABTS 활성소거능은 발효숙성 생강 이 $88.11-101.32 \%$ 로 $65.43 \%$ 의 일반생강 추출물보다 유의 적으로 높았으며, DPPH radical 소거능도 발효숙성 생강 추 출물이 10-20\% 정도 유의적으로 높은 결과를 보였으며 $(\mathrm{p}<0.05)$ 특히 $S$. thermophilus로 발효한 생강에서 가장 높았 다. 일반생강과 발효숙성생강 추출물의 항균효과를 확인하 고 활성의 차이를 비교하기 위하여 실시한 디스크확산법에 의한 결과는 그람양성균인 $S$. aureus와 L. monocytogenes 균주에서 발효숙성생강 추출물의 항균활성이 유의적으로 더 높은 것을 확인하였으며, 특히 $L$ brevis로 발효시킨 추출 물의 항균효과가 가장 높았다. 또한 그람음성균인 Salmonella spp. 균주에서도 일반생강에서는 clear zone이 관찰되지 않았으나, 발효숙성생강 추출물에서는 1.88-2.51 $\mathrm{cm}$ 의 clear zone을 확인하였다. 하지만 $E$. coli에서는 clear 
zone이 관찰되지 않았다. 최소억제농도인 MIC 결과 항균효 과를 위해 발효숙성생강보다 일반생강에서 보다 많은 양의 시료가 요구 되는 것으로 나타났다. 본 연구 결과 생강을 숙성 후 발효시키면 천연기능성 식품소재로서 radical 소거 및 항균활성이 높게 측정되었음을 확인하였으며, 발효 중 생강의 매운맛이 감소되었을 것으로 판단되어 향후 식품산 업에서 발효숙성생강을 이용할 때 항산화 및 항균성의 기초 자료가 될 것으로 여겨진다.

\section{감사의 글}

본 연구는 중소기업청에서 시행한 산학연협력기술개발 사업(C0445836)의 연구비 지원으로 수행된 연구결과의 일 부로, 이에 감사드립니다.

\section{References}

1. Kim NM, Lee JS (2003) Effect of fermentation periods on the qualities and physiological functionalities of the mushroom fermentation broth. Korean J Mycol, 31, 28-33

2. Lee YN (1996) Flora of Korea. Kyohaksa Co, Seoul, Korea, p 1107-1109

3. Lim TS, Kwon OJ, Kwon JH, Kim HG (2007) Monitoring of extraction yields and functional properties of ginger (Zingiber officinale) extracts using response surface methodology. J Korean Soc Food Sci Nutr, 36, 348-354

4. Jo MH, Ham IK, Lee GH, Lee JK, Lee GS, Park SK, Kim TI, Lee EM (2011) Composition of active ingredients between field grown and in vitro cultured rhizome of Korean nagative ginger (Zinigiber officinale Roscoe). Korean J Plant Res, 24, 404-412

5. Kim JS, Koh MS, Kim MK, Hong JS (1991) Volatile flavor components of Korean ginger (Zingiber officinale Roscoe). Korean J Food Sci Technol, 23, 141-149

6. Shin DH (1994) Survey on consumer concept and acceptability of convenient ginger product. Korea J Diet Culture, 9, 323-327

7. Connell DW, Sutherland MD (1969) A re-examination of gingerol, shogaol, and zingerone the pungent principles of ginger (Zingiber officinale Roscoe). Aust J Chem, 22, 1033-1043

8. Connell DW (1970) The chemistry of the essential oil and oleoresin of ginger (Zingiber officinale Roscoe). Flavour Ind, 1, 677-693

9. Lee BS, Ko MS, Kim HJ, Kwak IS, Kim DH, Chung
BW (2006) Separation of 6-gingerol from ginger (Zingiber officinale Roscoe) and antioxidative activity. Korean J Biotechnol Bioeng, 21, 484-488

10. Lee IK, Ahn SY (1985) The antioxidant activity of gingerol. Korean J Food Sci Technol, 17, 55-59

11. Hong JH (1989) Studies on the antioxidant activity of natural spices. MS thesis, Korea University, Korea $\mathrm{p}$ 11-32

12. Fujio H, Hiyoshi A, Asari T, Suminoe K (1969) Studies on the preventive method of lipid oxidation in freeze dried foods. Nippon Shokuhin Kogyo Gakka, 16, 241-246

13. Kim EJ, Ahn MS (1993) Antioxidative effect of ginger extracts. Korean J Soc Food Sci, 9, 37-42

14. Srivastava KC (1989) Effect of onion and ginger consumption on platelet thromboxane production in humans. Prostaglandins Leukotrienes Essent Fatty Acids, 35, $183-185$

15. Ryu HS, Kim J, Park SC, Kim HS (2004) Enhancing effect of Zingiber officinale Roscoe extracts on mouse spleen and macrophage cells activation. Korean J Nut, 37, 780-785

16. Park KY, Lee SJ, Lee KI, Rhee SH (2005) The antitumor effect in sarcoma-180 tumor cell of mice administered with Japanese apricot, garlic, or ginger doenjang. Korean J Food Cookery Sci, 21, 599-606

17. Van HT, Colin CD (2003) Effective anti-platelet and COX-1 enzyme inhibitors from pungent constituents of ginger. Thromb Res, 111, 259-265

18. Kim HS, Choi JH, Lee HJ, Jeong MC, Kim BS, Kim DM (2010) Quality characteristics of treated with mild heat and minced ginger during storage. Korean J Food Preserv, 17, 784-792

19. Ban YJ, Baik MY, Hahm YY, Kim HK, Kim BY (2010) Optimization of processing conditions for making a black ginger and design mixture for black ginger drinks. J Food Eng, 14, 112-117

20. Chun YG, Chung HY (2011) Quality properties of fermented gingers. Korean J Food Sci Technol, 43, 249-254

21. Sin JH, Choi DJ, Lee SJ, Cha JY, Kim JK, Sung NJ (2008) Changes of physicochemical components and antioxidant antivity of garlic during its processing. $\mathrm{J}$ Life Sci, 18, 1123-1131

22. AOAC (1980) Official methods of analysis $13^{\text {th }} \mathrm{ed}$, Association of Official Analytical Chemists, Washington DC, USA, $\mathrm{p}$ 4-12

23. Ra HN, Kim HY (2014) Quality characteristics and 
microbial safety of Sunsik with dandelion (Taraxacum platycarpum) complex extract powder (AF-343) for Home Meal Replacement. Korean J Food Cook Sci, 30, 642-649

24. Moreno MI, Isla MI, Sampietro AR, Vattuone MA (2000) Comparison of the free radical scavenging activity of propolis from several regions of Argentica. J Ethnophamacol, 71, 109-114

25. Re R, Pellegrini N, Proteggente A, Pannala A, Yang M, Rice Evans C (1999) Antioxidant activity applying an improved ABTS radical cation decolorization assay. Free Radical Biol Med, 26, 1231-1237
26. Kim YS, Jo CH, Choi GH, Lee KH (2011) Changes of antioxidative components and activity of fermented tea during fermentation period. J Korean Soc Food Sci Nutr, 40, 1073-1078

27. Shin BK, Kang SA, Han JI, Park SM (2015) Quality and sensory characteristics of fermented milk adding black carrot extracts fermented with Aspergillus oryzae. J Korean Soc Food Cult, 30, 370-376

28. Lee JY, Ahn MS (1994) Changes of antioxidative properties according to the heat-treatment of ginger extracts. Korean J Soc Food Sci, 10, 63-70

29. Jhoo JW (2008) Anti-inflammatory effects of purpurogallin carboxylic acid, an oxidation product of gallic acid in fermented tea. Korean J Food Sci Technol, 40, 707-711 